\begin{tabular}{lc}
\hline \multicolumn{1}{c}{ A N N A L E S } \\
UNIVERSITATIS MARIAE CURIE-SKŁODOWSKA \\
LUBLIN - POLONIA \\
VOL. XXII, 2 & SECTIOK \\
\hline
\end{tabular}

Wydział Politologii Uniwersytetu Marii Curie-Skłodowskiej w Lublinie

JAN PLESZCZYŃSKI

\title{
Intersubiektywność, rozumienie i porozumienie $w$ epoce nowych mediów i globalizacji
}

Intersubjectivity, Understanding, and Agreement in the Epoch of the New Media and Globalization

\begin{abstract}
ABSTRAKT
Artykuł dotyczy współczesnych problemów intersubiektywności. W intersubiektywności rodzi się rozumienie i porozumienie. Nowe media i procesy globalizacji sprawiają, że racjonalność, kultura i wiedza nie mogą stanowić jedynego fundamentu dla rozumienia i porozumienia - nie ma już bowiem wspólnej racjonalności, kultury $\mathrm{i}$ wiedzy, które dotychczas stanowiły ich podstawę.

W artykule argumentuję na rzecz tezy, że w świecie globalnym, ale jednocześnie rozfragmentaryzowanym na skalę nieznaną we wcześniejszych epokach medialnych, porozumienie jest znacznie istotniejsze niż rozumienie. Trzeba się porozumiewać nawet bez zrozumienia. Dlatego fundamentów porozumienia należy także szukać w racjomorficzności, a nie tylko w racjonalności; racjomorficzność jest wspólna wszystkim ludziom, bez względu na kulturę, religię, status społeczny, światopogląd itd.

„Pozytywną” formą racjomorficzności jest aksjomorfizm, w którym ujawnia się biologicznie warunkowana empatia i sympatia wobec przedstawicieli tego samego gatunku - Homo sapiens socialis et communicans. Odwołując się do idei Konrada Lorenza, proponuję, by Habermasowską racjonalność komunikacyjną nie tyle zastąpić, co uzupełnić komunikacyjną aksjomorficznością.
\end{abstract}

Słowa kluczowe: komunikacja, teoria komunikacji, nowe media, globalizacja, epistemologia, intersubiektywność, rozumienie, porozumienie, podmiotowość

WSTĘP

Efekty procesów globalizacji, w których bardzo istotną rolę odgrywa komunikacja zdominowana przez nowoczesne technologie medialne, mają ambiwalentny charakter: z jednej strony uniwersalizują, scalają i łączą, ale z drugiej różnicują, 
fragmentaryzują i dzielą ${ }^{1}$. Dlatego uznaję za niemal pewnik, że do najważniejszych i zarazem najbardziej palących problemów współczesności zaliczają się kwestie związane ze sferą intersubiektywności: rozumieniem i porozumieniem. Sądzę, że nowe propozycje teoretyczne i interdyscyplinarne ujęcia, wykazujące jakiś potencjał praktycznego wykorzystania, są potrzebą chwili.

Porozumienie i rozumienie nie są tym samym; porozumienie niekoniecznie musi być po-rozumieniem - następstwem rozumienia. Byłoby oczywiście wskazane i pożądane, żeby porozumienie stanowiło finalny i względnie trwały efekt rozumienia, ale współcześnie często nie jest to możliwe. Równie często efektem rozumienia jest nieporozumienie; właśnie dlatego że rozumiemy, nie możemy się porozumieć. Wydaje się więc, że w sferze społecznej porozumienie jest czymś istotniejszym od rozumienia ${ }^{2}$, zaś ze względu na różnicujące efekty globalizacji oraz wszechobecność i ogólnodostępność rozfragmentaryzowanej i skrajnie niespójnej wiedzy medialnej społeczna, polityczna i egzystencjalna ranga porozumienia jeszcze dodatkowo wzrasta 3 .

Inspiracją tego artykułu była sytuacja Europy w 2015 r., zdefiniowana przez przybycie niespodziewanie wielkiej liczby uchodźców i imigrantów z Bliskiego Wschodu i Afryki Północnej oraz dramatyczne okoliczności towarzyszące migracjom. Ubiegłoroczne wydarzenia odsłoniły liczne słabości i sprzeczności struktur europejskich, przypomniały też o kruchości demokracji liberalnej oraz judeochrześcijańskich i oświeceniowych wartości, na których została ufundowana cywilizacja Zachodu i współczesna Europa. Z różnych stron pojawiły się ostrzeżenia, że żyjemy w przededniu kryzysu grożącego nie tylko dezintegracją Unii Europejskiej, ale erozją dominującej w świecie zachodnim demokracji liberalnej. Marcin Król [2015: 16] stwierdził, że stawką tego kryzysu jest „,podtrzymanie istniejącej demokracji”.

1 W artykule nie definiuję pojęcia „globalizacja”; nie ma tu takiej potrzeby. Najogólniej można przyjąć, za Markiem Pietrasiem [2002] i wieloma innymi autorami, np. Marią Marczewską-Rytko [2002], że ten nieostry termin odnosi się do wielu różnorodnych, czasem niewspółmiernych procesów występujących na różnych poziomach i w różnych dziedzinach życia społecznego. Nie ma jednej globalizacji, lecz wiele różnych procesów globalizacji. W artykule skupiam się na problemach epistemologicznych i dlatego prawie zupełnie pomijam kwestie ekonomiczne; zdaję sobie jednak oczywiście sprawę, że odgrywają one wiodącą rolę w procesach globalizacji i komunikacyjnej rewolucji cyfrowej. W dalszej części artykułu globalizację określam jako „otwieranie się kultur” i „poszerzanie otoczenia człowieka” (piszę o otoczeniu, a nie środowisku, jednak wyjaśnienie różnicy między tymi pojęciami wymagałoby napisania odrębnego artykułu). Warto może dodać, że badacze globalizacji do dziś często powołują się na różne znaczenia tego terminu zawarte w książce Rolanda Robertsona [1992].

2 Przykładem rangi porozumienia w sferze społecznej jest tzw. poprawność polityczna; chodzi w niej przede wszystkim o porozumienie mimo niedostatku rozumienia.

3 Kiedy mówię o „wiedzy medialnej”, mam na myśli to, że dzisiaj prawie wszystko, co wiemy, wiemy z mediów masowych i nowych. Nowoczesne technologie komunikacyjne sprawiają, że kultura przekształca się w cyfrową technokulturę medialną. Współcześnie nowe media, jako narzędzia i środowisko komunikacji, dyktują relacje człowieka z innymi ludźmi, naturą i kulturą. 
Zauważył, że kryzys ekonomiczny z lat 2008-2011 był „niewielki” w porównaniu do tego, który nadchodzi i daleko wykracza poza problemy ekonomiczne 4 .

Dynamika współczesnych procesów społecznych jest tak ogromna, że nie ośmielam się prognozować, jak będzie wyglądać Europa i świat za kilka miesięcy, gdy ten artykuł ewentualnie ukaże się drukiem ${ }^{5}$. W epoce globalizacji i nowoczesnych technologii następuje przyspieszenie wszystkiego; to, co aktualne dzisiaj, jutro zwykle nie jest już aktualne ${ }^{6}$. Ale demokracja liberalna, o ile wbrew ponurym prognozom przetrwa, zawsze będzie strukturą labilną i kruchą - bo taka jest w swojej istocie. Jej niestabilność ujawnia się szczególnie mocno w okresach kryzysów ekonomicznych i politycznych.

Nie wolno przeoczyć, że o ekonomii i polityce ostatecznie decyduje komunikacja; rządzi ekonomią (głównie w postaci giełdy i reklamy), polityką (przez media masowe i nowe) i wszelkimi innymi zjawiskami społecznymi. $Z$ tego powodu refleksja politologiczna powinna uwzględniać komunikację - obszar intersubiektywności, rozumienia i porozumienia. W życiu społecznym porozumienie ma rangę pierwszorzędną. Dlatego w epoce globalizacji i nowych mediów, którą charakteryzuje brak wyróżnionego centrum kultury i rozfragmentaryzowana wiedza, konieczne jest odnalezienie lub wskazanie czegoś, co stanowi albo może stanowić fundament porozumienia między ludźmi różnych kultur, tradycji, religii, o różnym statusie społecznym, diametralnie odmiennych doświadczeniach życiowych - mówiąc najogólniej: ludźmi o niewspółmiernych umysłach. Innymi słowy, trzeba odwołać się do czegoś, co jest wspólne wszystkim ludziom i można na tym budować sferę intersubiektywności i porozumienie. Taką próbę podejmuję w tym artykule.

Przyjmuję perspektywę ewolucyjną, ewolucja bowiem jest uniwersalnym prawem świata ożywionego, obejmującym także społeczności i to, co te społeczności wytwa-

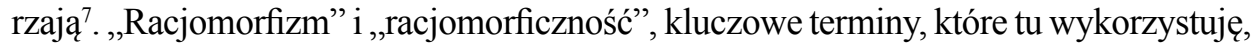

${ }^{4}$ Gdy mowa o kryzysie, warto jednak pamiętać, że etymologia tego słowa odsyła do medycyny; kryzys to stan przesilenia, chory może umrzeć, ale może też wyzdrowieć. Wcale nie jest zatem wykluczone, że z obecnego kryzysu Unia Europejska i demokracja wyjdą wzmocnione, a nie osłabione.

5 W okresie, gdy pisałem ten artykuł, 13 listopada 2015 r., wydarzył się zamach terrorystyczny w Paryżu, zorganizowany przez tzw. Państwo Islamskie. Z całą pewnością zamach ten, wpisujący się według trafnego określenia Krzysztofa Rutkowskiego [2015: 30] - w „pełzającą wojną światową” będzie miał poważne i trudne do przewidzenia konsekwencje nie tylko dla polityki imigracyjnej Unii Europejskiej i poszczególnych państw członkowskich; w epoce globalizacji wszelkie tego typu zdarzenia skutkują na wielu płaszczyznach i mają wymiar globalny.

6 Pisząc o przyspieszeniu wszystkiego, nawiązuję do głośnej książki Jamesa Gleicka [2003] Szybciej. Przyspieszenie niemal wszystkiego. W angielskim oryginale książka ukazała się w 1999 r., dlatego autor pisał o ,przyspieszeniu niemal wszystkiego” (acceleration of just about everything). Dziś zapewne pominąłby słowo „niemal”.

7 Oczywiście trzeba rozróżniać różne typy ewolucji, np. biologiczną, kulturową, technologiczną. Łączą je uniwersalne prawa, różni skala czasowa. 
zaczerpnąłem ze słownika ewolucyjnej teorii poznania ${ }^{8}$, natomiast w tle moich rozważań znajduje się terminologia związana z teorią komunikacji Jürgena Habermasa. Jeśli nawet część jego idei i pojęć można uważać za nie w pełni adekwatne do współczesnej komunikacji zdominowanej przez nowe media, to w artykule o zjawiskach komunikacyjnych nie można ich zignorować. Habermas nie tylko stworzył imponujący gmach teorii komunikacji, ale jest, jak słusznie zauważył Kenneth Baynes [2008: 635], ,jedną z najbardziej wpływowych postaci współczesnej teorii polityki”.

\section{KOMUNIKACJA JAKO RELACJA WIĘZIOTWÓRCZA, POZNAWCZA \\ I WIEDZOTWÓRCZA}

Komunikacja stanowiła konieczny warunek wybicia się człowieka ponad stan zwierzęcia - bez niej pozostałby „zwykłym” gatunkiem, takim jak każdy inny. Już Księga Rodzaju ukazuje rangę komunikacji w życiu swoiście ludzkim: Bóg stworzył człowieka w dwóch różnych, ale komplementarnych postaciach. Wprawdzie Adam mógłby poznawać rośliny, zwierzęta i minerały za pomocą naturalnych, biologicznych aparatów światoobrazu ${ }^{9}$, czyli na sposób zwierząt, ale nie mógłby niczego dowiedzieć się o sobie samym; swoje człowieczeństwo mógł odkryć tylko w komunikacji z Ewą. Ta biblijna opowieść podpowiada, że komunikacja to nie tylko więź, ale też warunek istnienia i rozwoju wiedzy obiektywnej (w sensie Popperowskim [Popper 1992]); ludzka wiedza ma charakter społeczny, a o wyjątkowości człowieka decyduje intersubiektywność. Bez komunikacji nie byłoby ani kultury, ani wspólnej wiedzy. W najogólniejszym, filozoficznym sensie, komunikacja jest relacją więziotwórczą, poznawczą i wiedzotwórczą.

Więź to kategoria witalna, niezwykle istotna w kontekście przetrwania. Wspólnoty i społeczeństwa bazują na więziach, które w procesach komunikacji powstają, są podtrzymywane, ulegają modyfikacjom, degenerują się i giną. W zbiorowościach zwierzęcych o więziach decyduje ,głęboka” subiektywność: geny, instynkty, odruchy, biologicznie determinowane rytuały, gesty, pozy i sygnały, które - wedle nomenklatury Konrada Lorenza [1953: 96-110; zob. też Galton 1990] - są językiem zwierząt. Komunikacja i jej wyrafinowane narzędzie - mowa - umożliwiły człowiekowi wydobycie się z ,głębokiej” subiektywności i wejście w intersubiektywność.

Dzięki komunikacji możliwa jest kultura, gatunkowy wyróżnik Homo sapiens socialis et communicans. Nieobecna w świecie innych organizmów żywych kultura jest realną ontycznością w świecie ludzkim, jedynym, jaki znamy i do jakiego mamy

8 Termin ,racjomorficzność” wprowadził psycholog Egon Brunswik [1955: 108-109], ale spopularyzowali w następnych dekadach ewolucyjni epistemologowie, głównie Konrad Lorenz, Rupert Riedl i Gerhard Vollmer, w Polsce zaś m.in. Władysław Kunicki-Goldfinger, Ignacy S. Fiut, Aldona Pobojewska.

9 Termin ,aparaty światoobrazu” (Weltbildapparat) pochodzi ze słownika ewolucyjnych epistemologów [zob. np. Lorenz 1977: 40-41]. Mówiąc w pewnym uproszczeniu, są to narządy zmysłów; każdy żywy organizm ma gatunkowo swoisty aparat światoobrazu. Karl Popper określał go terminem perceiving apparatus. 
dostęp. W odróżnieniu od zwierząt, których procesy poznawcze trafnie opisuje Kartezjańska diada podmiotowo-przedmiotowa, w poznanie ludzkie zawsze zaangażowana jest kultura; pełni fundamentalną rolę epistemiczną i epistemologiczną. Wszystkie doniesienia naturalnych aparatów światoobrazu, które nie pozostają trwale w podświadomości, są filtrowane przez kulturę nadającą postrzeganym obiektom i relacjom znaczenia i sensy. Człowiek zaś ma dostęp do kultury dzięki komunikacji i mediom. Dlatego określające formy komunikacji media mają tak ważne znaczenie w życiu indywidualnym i społecznym.

Niemniej jednak stale należy pamiętać, że u podstaw wszelkich zjawisk, działań i zachowań komunikacyjnych zawsze w końcu odnajdziemy naturę ${ }^{10}$. Pod cienką warstwą kultury skrywają się grube pokłady naszej zwierzęcej składowej - efekt milionów lat ewolucji. Dlatego w studiach nad komunikacją trzeba uwzględniać także biologiczne aspekty komunikacji, np. zachowanie stwarzające pozór celowego działania komunikacyjnego może mieć charakter teleonomiczny ${ }^{11}$.

Komunikacja najczęściej traktowana jest jako zjawisko kulturowe, ale genealogia wskazuje na jej hybrydowy status ontyczny. Ta, którą znamy dzisiaj, wywodzi się z natury, siły znacznie starszej i mocniejszej od kultury i często z nią skonfliktowanej. Zawieszony pomiędzy naturą i kulturą człowiek poddany jest presji biologicznych i kulturowych determinacji i przymusów, ujawniających się także w komunikacji. Jak pisałem w innej publikacji [Pleszczyński 2013: 45], „na pierwotne biologiczne a priori nakłada się, i często z nim koliduje, a priori kulturowe. Kolizja ta oznacza pojawienie się niepewności i problematyczności, i paradoksalnego pytania o to, której konieczności się podporządkować: uwierzyć ludziom - czyli kulturze, czy pozostać przy własnych wrażeniach i intuicjach - czyli uwierzyć biologii"12.

\section{RACJOMORFICZNOŚĆ, RACJONALNOŚĆ, KOMUNIKACJA}

Konsekwencją hybrydowego statusu ontycznego komunikacji jest to, że we wszelkich zjawiskach komunikacyjnych można wyróżnić składową racjonalną

${ }^{10} \mathrm{~W}$ perspektywie ewolucyjnej zjawiska komunikacyjne przejawiają się nie tylko w działaniach, ale także w zachowaniach. W naukach o komunikacji przeważa stanowisko, że komunikacja jest intencjonalnym działaniem, a nie zachowaniem [zob. np. Wendland 2014: 178-187]. Z kolei niektórzy radykalni konstruktywiści uważają, że wszystko jest komunikacją.

${ }^{11}$ Termin „teleonomia” spopularyzował wybitny biolog ewolucyjny Ernst Mayr, ale do słownika biologii wprowadził go Collin S. Pittendrigh. Zasadniczo chodziło im o to, by z biologii wyeliminować kategorię celowości; wiadomo bowiem, że ewolucja nie działa celowo. Teleonomię można traktować jako quasi-teleologię [zob. Spaemann, Löw 2008: 369-384].

${ }^{12}$ Rangę biologicznego a priori wyeksponował Kant, który nauczał o formach czystej naoczności i kategoriach umysłu, gatunkowo swoistych, wrodzonych determinantach wyznaczających ramy możliwego doświadczenia. Ewolucyjni epistemologowie odkryli jednak, że Kantowskie a priori uwzględniało tylko perspektywę synchroniczną, jest więc ontogenetycznym a priori; w perspektywie diachronicznej jawi się ono jako filogenetyczne a posteriori. 
i racjomorficzną; oczywiście wyróżnić analitycznie, bo w realnym świecie są one zawsze sprzężone, przenikają się i nakładają. Racjomorficzność - podobnie jak racjonalność - definiowana jest różnie; najogólniej oznacza ona „warunkowane genetycznie, nieświadome, ale teleonomicznie ukierunkowane na przeżycie zdolności poznawcze organizmów żywych" [Pleszczyński 2015: 62]. Choć działania racjomorficzne - np. wytwarzanie przez pszczoły plastrów miodu w postaci foremnych sześciokątów ${ }^{13}$ - sprawiają wrażenie działań racjonalnych i celowych, to takimi nie są; mają charakter racjomorficzny i teleonomiczny, quasi-racjonalny i quasi-celowy. Racjomorficzność to wykształcone w toku filogenzy gatunkowo swoiste formy zachowania, poznawania i poznania, ,głęboka” subiektywność, nośnik kluczowych dla przeżycia ,intuicji” na temat ,świata”. Z teorii ewolucji wiadomo, że także u ludzi racjomorficzność, stanowiąca dziedzictwo filogenezy, jest trwale obecna.

W głośnej kilka dekad temu, a dzisiaj nieco zapomnianej książce Regres człowieczeństwa Konrad Lorenz pisał [1986: 68]: „Analogia między racjonalnymi procesami myślenia uznawanymi przez najradykalniejszych scjentystów za naukowo prawomocne, a racjomorficznymi wydolnościami postrzegania jest niezwykle przekonującym argumentem na to, że takie wydolności poznawcze, które z całą pewnością nie mają charakteru racjonalnego, muszą również zostać zaakceptowane jako prawomocne źródła naukowego poznania. Procesy racjonalne i racjomorficzne stanowią dalszy przykład tego, że nasz aparat poznawczy mógł niejednokrotnie wykształcić dwa różnorakie, niezależne od siebie funkcjonujące narządy do spełniania tego samego zadania. Zaniedbywanie jakiejkolwiek wydolności poznawczej jest jednoznaczne ze zrezygnowaniem z wiedzy, a jest to największe wykroczenie przeciwko duchowi poszukiwania prawdy, jakiego nie może dopuścić się uczony". Jak widać, racjomorficzności nie wolno utożsamiać z irracjonalnością. Opozycje: racjonalność-irracjonalność oraz racjonalność-racjomorficzność, należą do różnych porządków: pierwsza wpisuje się w porządek epistemologiczny, druga w porządek ontologiczny.

Racjomorficzność nie przemawia do człowieka językiem ukierunkowanym na wartości kulturowe, lecz na wartości witalne, bezpośrednio służące przetrwaniu. „Wiedza” racjomorficzna to pierwotne intuicje dotyczące natury; wiedzą racjonalną mogą się stać po przefiltrowaniu przez kulturę i w testach dokonanych w komunikacji. Dopiero wówczas można ją uznać za wiedzę obiektywną w sensie Popperowskim ${ }^{14}$. Niemniej jednak mechanizmy racjomorficzne, jako ewolucyjnie starsze,

13 Jest to optymalny kształt, bo spośród wszystkich wielokątów sześciokąt foremny ma najkorzystniejszy stosunek powierzchni do obwodu, a więc pozwala na użycie najmniejszej ilości wosku. Innym przykładem wrodzonej wiedzy racjomorficznej może być to, że ssaki tuż po narodzeniu ,wiedzą”, że muszą i potrafią ssać.

14 Tradycyjnie, za Platonem, wiedzę przypisuje się tylko ludziom - dlatego słowo „wiedza” ująłem w cudzysłów. Ewolucyjni epistemologowie uważają jednak, że można mówić o wiedzy wrodzonej, apriorycznej, w którą są wyposażone wszystkie organizmy żywe. Oczywiście jest ona tylko ontogenetycznie a priori, natomiast filogenetycznie jest wiedzą a posteriori. Warto tu dodać, że Karl Popper przyjaźnił się z Konradem Lorenzem i zasadniczo zgadzał się z większością jego idei [Popper 1987, 1992; Popper, Lorenz 1985]. 
a więc znacznie lepiej zweryfikowane w procesie ewolucji niż relatywnie młode mechanizmy kulturowe, pełnią bardzo ważne funkcje życiowe: odpowiadają za pierwsze i natychmiastowe rozpoznanie obiektu, oceniają jego siłę i ,intencje”, wiążące się z nim zagrożenia i ewentualne pożytki, podpowiadają błyskawiczną i jednoznaczną reakcję. Ponieważ mechanizmy te są wrodzone, „wiedza” racjomorficzna jest bezwarunkowa i niepowątpiewalna. Wątpienie jest już oznaką racjonalności ${ }^{15}$. Zwierzę nie wątpi, działa i zachowuje się wedle reguł zerojedynkowych: zbliż się-uciekaj, pociągające-wstrętne, bezpieczne-groźne itd. Ukierunkowana na jednoznaczność zerojedynkowość to istota mechanizmów racjomorficznych, w które jest wyposażony każdy żywy organizm. Racjomorficzność człowieka to sfera automatyzmów i emocji, Freudowskie id.

Niektóre z działań i zachowań racjomorficznych mogą nam się wydawać nacechowane aksjologicznie, ale wiemy, że tylko u ludzi występują reakcje stricte aksjologiczne, podejmowane pod wpływem ustanowionych społecznie i chronionych wartości i norm. Takie quasi-aksjologiczne działania i zachowania nazywam aksjomorficznymi ${ }^{16}$. Jak widać, w perspektywie ewolucyjnej pierwsze oznaki kryterium dobra i zła odnajdujemy już w naturze.

Wprawdzie kultura thumi w człowieku mechanizmy racjomorficzne, nadając im akceptowalne społecznie formy wyrażania emocji, ale racjomorfizmu nie eliminuje; w momentach zagrożenia ujawnia się on z całą swoją mocą. Biologiczny racjomorfizm stanowi komplementarne i życiowo niezbędne dopełnienie mechanizmów kulturowych i reguł racjonalnych. Tak więc ewolucyjnie sprzężona z sygnalizacją zwierząt ludzka komunikacja ma tylko częściowo racjonalny charakter; racjomorfizm jest w niej stale obecny, nakłada się na zachowania i reakcje dyktowane przez kulturę, która ukierunkowuje ku racjonalności i aksjologii.

Od czasów Galileusza i Newtona najwyższy stopień racjonalności przypisuje się wiedzy naukowej, ponieważ ze wszystkich rodzajów wiedzy dostępnej człowiekowi jest najbardziej wiarygodna i najpewniejsza. Mówiąc językiem epistemologii, wiedza naukowa w największym stopniu spełnia ideały epistemiczne, do których należy także racjonalność ${ }^{17}$. Nauka, a wraz z nią racjonalność, zawsze stanowiła wielką i wspaniałą ideę globalizacyjną, choć dziś coraz bardziej widać, że jest to idea niespełniona; nauka i racjonalność zostały zawłaszczone, wykorzystane i w pełni kontrolowane przez technologię i pragmatykę. Jak pisał ponad 30 lat temu, a więc jeszcze w epoce przedinternetowej, Stefan Amsterdamski [1983: 181-182], racjonalność naukową sprowadza się zwykle do ,technik efektywnego działania, manipulowania przedmiotami i symbolami”, zaś „,nauka ceniona jest przede wszystkim

15 Jak pamiętamy, Kartezjusz - jeden z najbardziej konsekwentnych racjonalistów w dziejach Zachodu - postulował metodyczne wątpienie jako metodę naukową.

${ }^{16} \mathrm{Z}$ terminem „aksjomorfizm”, ukutym przez analogię z terminem „racjomorfizm” nie spotkałem się w literaturze; niewykluczone zatem, że jest mojego autorstwa.

${ }^{17}$ Innymi ideałami epistemicznymi są np. prawda, koherencja, wiarygodność, weryfikowalność, falsyfikowalność itp. 
jako narzędzie podnoszenia efektywności ludzkich działań praktycznych. Jest to pogląd na naukę szeroko współcześnie rozpowszechniony, zgodnie z którym poznawcza funkcja wiedzy podporządkowana zostaje jej funkcji technologicznej"18. Procesy globalizacji i nowe technologie medialne napędzają i wzmacniają ten trend i zapewne z tego powodu wybitny filozof Jan Woleński [2015: 37] napisał: „Losy nowożytnego ideału nauki przekonują, że z jednej strony nauki nie da się zastąpić niczym innym, ale z drugiej bezkrytyczna wiara w naukę prowadzi do istotnych zagrożeń cywilizacyjnych. Ta diagnoza jest szczególnie ważna w dobie globalizacji”. Odwołując się do biologicznej metafory, można powiedzieć, że współczesna globalizacja wspomagana przez nowoczesne technologie przypomina bardziej inżynierię genetyczną niż ewolucję.

Epoka nowożytna spłyciła pojęcie racjonalności, zostało ono sprzężone z racjonalizacją, efektywnym działaniem, pragmatycznym ustalaniem takiego porządku myśli, który musi być konkluzywny dla działania; w przeciwnym razie myśli nie mają wartości. W takim podejściu do racjonalności widać wyraźne powinowactwa z działaniami strategicznymi, wyróżnionymi przez Habermasa w jego szeroko znanej i - pomimo różnorakich zastrzeżeń i polemik - powszechnie akceptowanej w naukach społecznych i humanistyce teorii komunikacji [Szacki 2003: 930].

Sądzę, że nowe media, nowe sposoby komunikacji i nowe formy globalizacji wymuszają, a co najmniej prowokują do wprowadzenia pewnych dopowiedzeń do teorii Habermasa, eksponującej racjonalność komunikacyjną. Myślę, że dokonany przez niego już blisko 40 lat temu - a więc w epoce mediów tradycyjnych i softglobalizacji, o której piszę nieco dalej - podział na działania strategiczne i działania komunikacyjne w obecnych warunkach społecznych, politycznych, kulturowych, cywilizacyjnych, technologicznych itd. domaga się nowych interpretacji, wyraźniej uwzględniających i ukierunkowanych na czynniki racjo- i aksjomorficzne, stale obecne w komunikacji i sferze intersubiektywności.

W dalszej części artykułu przedstawię pewne własne koncepcje i propozycje w tej kwestii, tutaj zaś, upraszczając i w wielkim skrócie - a więc nieuchronnie także zniekształcając oryginalną myśl - przypomnę tylko, że wedle Habermasa [1999, $2002 \mathrm{i}$ in.] działania strategiczne polegają na skutecznym, wykorzystującym pełen zestaw technik perswazyjnych, przekonywaniu innych ludzi do określonego celu. Działania strategiczne mają więc techniczny i instrumentalny charakter; istotny jest efekt, środki zaś mają być adekwatnie, tzn. racjonalnie, dobrane do celu ${ }^{19}$. Cho-

${ }^{18}$ Inne, bardziej optymistyczne ujęcie racjonalności proponował Popper, który utożsamiał ją z metodą naukową, stanowiącą wzorzec krytycyzmu; w takim ujęciu racjonalność jest nie tyle efektywnym narzędziem racjonalizacji życia społecznego, co metodą eliminowania błędów i przybliżania się do prawdy.

${ }^{19}$ Pamiętamy jednak, że to, co uznaje się za racjonalne, ma historyczny charakter. 
dzi o to, by w sposób maksymalnie skuteczny ukierunkować ludzi na współpracę i współdziałanie w realizacji jakiegoś celu, który wszyscy - właśnie w wyniku działań strategicznych - uznają za ważny, mimo że niekoniecznie muszą go rozumieć. Działania strategiczne mają sprawić, że każdy człowiek zaakceptuje swoje miejsce i zadania w realizacji celu. Jak widać, działania strategiczne mają charakter stricte polityczny, ich wyznacznikiem jest skuteczne wywieranie wpływu na ludzi. Niemniej jednak zasadzają się na idei porozumienia: co do celu, miejsca i zadań. Natomiast w działaniach komunikacyjnych chodzi o porozumienie innego rodzaju, w innej płaszczyźnie; chodzi o odnalezienie wspólnych przekonań dotyczących jakiegoś fragmentu czy aspektu rzeczywistości - ludzkiego świata, świata życia, Lebensweltu; to dopiero pozwala myśleć o ewentualnym współdziałaniu.

Innymi słowy, w działaniach strategicznych najważniejsze jest porozumienie co do celu, bo cel jest najważniejszy, natomiast w działaniach komunikacyjnych najważniejsza jest wspólna interpretacja. Efektem działań strategicznych ma być zgodna, sprawna, bezkonfliktowa, może nawet bezrozumna współpraca. Działania strategiczne mają skutecznie ,pracować” - i to wszystko; współpraca może więc być osiągana np. obietnicą gratyfikacji albo przeciwnie - groźbą sankcji itp. Działania komunikacyjne sytuują się natomiast w zupełnie innej perspektywie: chodzi o to, by prowadziły do wspólnej interpretacji pewnych, nawet mało - pozornie lub obiektywnie - znaczących faktów, zdarzeń, zjawisk, procesów, wartości, interesów itd.; we wspólnej interpretacji rodzi się bowiem więź i międzyludzkie porozumienie. Habermas słusznie podkreślał [1999: 640], że porozumienie jest istotą intersubiektywności, ale jak sądzę, nieco przeceniał rolę czynników racjonalnych, a nie docenił racjomorficzności. Epoka globalizacji i nowych technologii, którą jako pierwsi przewidzieli i wstępnie, choć nie zawsze trafnie, zdiagnozowali filozoficzni postmoderniści, tylko wzmacnia wątpliwości, czy współcześnie racjonalność może być dostatecznie mocnym filarem i fundamentem porozumienia.

Wedle Habermasa porozumienie uzyskuje się w publicznej debacie, racjonalnym dyskursie. Trzeba jednak zauważyć, że zręby swojej teoretycznej koncepcji Habermas tworzył w epoce przedinternetowej. Współcześnie natomiast w sferze publicznej dominuje e-dyskurs, odbywający się za pośrednictwem, z udziałem i „,w” nowych mediach, stanowiących jednocześnie narzędzie i środowisko komunikacji, zaś sama komunikacja przybiera nieznaną we wcześniejszych epokach medialnych formę, którą Manuel Castells [2013] nazwał ,masową komunikacją zindywidualizowaną". E-dyskurs, traktowany en bloc, nie spełnia nawet minimalnych standardów epistemicznych, czyli kryteriów racjonalności [Pleszczyński 2011]. W e-dyskursie znaczenia - zamiast się wyostrzać - stają się coraz bardziej niejasne; pojęcia tracą wspólne znaczenia na rzecz oznaczania; oznaczają stany umysłu, emocji i indywidualnych przekonań anonimowych zazwyczaj uczestników e-dyskursu.

Nowe media napędzają i wspomagają racjomorficzność w komunikacji. Technologie cyfrowe ze swej istoty działają według zerojedynkowych mechanizmów, zaś w nowych mediach komunikację osób zastępuje komunikacja anonimów lub 
cyfr; w e-dyskursie osoba bardzo często zostaje zredukowana do osobnika, członka stada czy sfory, którego jedyną „obiektywną” identyfikacją jest cyfrowa maska w postaci numeru IP. Jak przekonująco wykazywał Elias Canetti [1996], stado i sfora organizują się według reguł racjomorficznych. Współczesne technologie są kryjówką i siedliskiem racjomorfizmu, jednocześnie wymuszając i promując racjomorficzne działania i zachowania ${ }^{20}$. Inną przeszkodę w uzyskiwaniu porozumienia stanowi to, że komunikacja w nowych mediach nie wymaga prawie żadnych kulturowych kompetencji komunikacyjnych; jedynym progiem wejścia do e-dyskursu jest próg technologiczny, elementarna, intuicyjno-racjomorficzna umiejętność obsługi komputera $^{21}$. Najogólniej mówiąc, degeneracyjna redukcja komunikacji w nowych mediach polega na tym, że rządzą nią reguły technologiczne i rynkowe oraz jest wyprana $\mathrm{z}$ aksjologii. Brak aksjologii stanowi bardzo poważną przeszkodę dla porozumienia, bo w komunikacji specyficznie ludzkiej pełni ona rolę pierwszoplanową. W obrębie intersubiektywności to, co jest prawem życia społecznego, przekłada się na przymus, a co najmniej uzasadnioną powinność moralną. Tego typu barier na drodze do porozumienia i rozumienia można wymienić znacznie więcej. Tutaj, podsumowując ten fragment artykułu, wystarczy powiedzieć, że nowe media przekształcają Habermasowski ideał racjonalnego dyskursu w racjomorficzny e-dyskurs.

Trzeba też zauważyć, że ze względu na medialny i rozfragmentaryzowany charakter wiedzy w epoce globalizacji i nowych mediów bardzo problematyczna staje się możliwość spełnienia tzw. roszczeń ważnościowych w komunikacji (najczęściej przywołuje się roszczenia do prawdy, słuszności i intencji). Wedle Habermasa ludzie kierują się tymi roszczeniami i oczekują od innych ich respektowania. Nie ma tu miejsca ani potrzeby szczegółowego omawiania tych roszczeń; wydaje się jednak, że nie mają one zastosowania (albo ostrożniej: mają znacznie ograniczone zastosowanie) we współczesnej komunikacji zdominowanej przez nowe media, bo - po pierwsze - anonimowa masa nie respektuje ani nie spełnia żadnych roszczeń, po drugie zaś mają one charakter wybitnie teoretyczny, racjonalny, angażujący myślenie pojęciowe i abstrakcyjne. $Z$ tego powodu w globalnym świecie niewspółmiernych kultur, rozfragmentaryzowanej wiedzy i anonimowych przekazów Habermasow-

${ }^{20}$ Aby to zilustrować, w kilku publikacjach posługiwałem się przykładem dość powszechnie akceptowanej w globalnym środowisku akademickim zasady ,publikuj albo giń”. Aksjologiczna składowa tej zasady (publikuj), nakazująca dzielenie się wiedzą, została uzupełniona składową racjomorficzną (giń), bazującą na konkurencji typu Darwinowskiego. Praktyczne stosowanie tej zasady umożliwiają nowe technologie, stwarzające zupełnie nowe, technologiczne „taśmy produkcji” publikacji naukowych. Reguły kulturowe są zniesione; naukę organizują jednoznaczne zerojedynkowe procedury - są to działania strategiczne, ukierunkowane na cel uznany w danym momencie za racjonalny, choć wcale taki nie musi być.

${ }^{21}$ Użytkowanie komputera i innych nowych mediów wymaga tylko umiejętności przyciskania odpowiednich guziczków - i współcześnie tego typu kompetencje posiada prawie każde dziecko w wieku szkolnym; w efekcie każdy, kto posiada te elementarne kompetencje, może stać się pełnoprawnym uczestnikiem każdego e-dyskursu. We wcześniejszych epokach medialnych dostęp do różnorakich dyskursów napotykał dużo więcej barier i wymagał wykazania się różnymi kompetencjami, zwykle potwierdzonymi także formalnie. 
skie roszczenia stanowią bardzo trudną do sforsowania przeszkodę komunikacyjną i epistemologiczną. Choć na poziomie podstawowych faktów dotyczących życia codziennego ludzie stosunkowo łatwo mogą się zrozumieć i porozumieć, to na poziomie abstrakcji - takich jak prawda, słuszność, intencja - rozumienie i porozumienie bardzo często jest po prostu nieosiągalne ${ }^{22}$.

Jeśli rzeczywiście jest tak, że na bazie racjonalnego dyskursu i roszczeń ważnościowych współcześnie coraz trudniej odnajdywać wspólne znaczenia - a praktyka zdaje się to potwierdzać - to dla porozumienia trzeba poszukać jakiegoś innego fundamentu; takiego, który byłby wspólny dla wszystkich, bez względu na różnice kulturowe, cywilizacyjne, etniczne, religijne itd. Być może jedynym możliwym wspólnym mianownikiem okaże się aksjomorficzność - pochodna racjomorficzności; przemawia za nią to, że wszyscy należymy do tego samego gatunku. Niewykluczone więc, że racjonalność komunikacyjną Habermasa trzeba będzie uzupełnić (a może nawet zastąpić) komunikacyjną aksjomorficznością, tym, co - wprawdzie emocjonalnie i bezrefleksyjnie - służy jednak wartościom ogólnoludzkim, czyli humanistycznym.

Oczywiście natychmiast nasuwa się ważne i niepokojące pytanie, czy taki ,zwrot aksjomorficzny" nie doprowadzi do dalszego rozmontowywania sfery publicznej i dalszej degeneracji sfery intersubiektywności, dotychczas wiązanych z kulturą, racjonalnością i rozumem analitycznym, i nie zniweczy trwających tysiące lat wysiłków, gdy w antropogenezie człowiek mozolnie przebijał się z racjomorfizmu ku rozumności i racjonalności. Tym, co go wyróżniło spośród innych gatunków zwierząt, jest kultura, język i rozum, zaś racjomorficzność to emocje, bezrefleksyjność i automatyzmy.

\section{INTERSUBIEKTYWNOŚĆ: KOMUNIKACJA, WSPÓŁPRACA I WALKA}

Komunikacja jest prawem, imperatywem, determinantą i formą życia społecznego, warunkiem intersubiektywności, więzi międzyludzkich, wiedzy, kultury. Brak komunikacji oznaczałby ewolucyjny regres; jako przedstawiciele Homo sapiens socialis et communicans musimy się komunikować [Watzlawick 1967: 48-54; Skibiński 2012: 82-83].

\footnotetext{
${ }^{22}$ Np., jak pisała fizyk i filozof nauki Elżbieta Kałuszyńska [2005: 122], ,i Hutu, i Zande, i Europejczyk wiedzą, że rozlana woda wsiąknie w ziemię, że ogień parzy i może spowodować pożar, że niektóre zwierzęta są drapieżne, inne zaś żywią się roślinami, że pewne owoce są pożywne i smaczne, że strącony z góry kamień potoczy się w dół, a połknięcie rybiej ości może mieć przykre konsekwencje". Kałuszyńska wskazała na obszerne fragmenty wspólnej wszystkim ludziom wiedzy i słusznie przeciwstawiła się radykalnemu konstruktywizmowi. Należy jednak zauważyć, że na poziomie wysokiej abstrakcji występują poważne trudności w rozumieniu i porozumieniu. To, że wszyscy zgodzą się, iż formuła „, $2+$ $2=4$ " zawiera prawdę, nie znaczy, że wszyscy tak samo pojmują „,prawdę". W tym kontekście warto też przywołać książkę amerykańskiego psychologa Richarda Nisbetta Geografia myślenia. Dlaczego ludzie Wschodu i Zachodu myśla inaczej?, w której autor przekonująco dowiódł głębokich różnic w schematach myślowych ludzi różnych kultur.
} 
Dwie inne determinanty i formy życia społecznego stanowią współpraca i walka. Wraz z komunikacją są też formami intersubiektywności, ściśle ze sobą sprzężonymi - tworzą nierozerwalną triadę: komunikacja warunkuje i kształtuje przebieg, sposoby i formy współpracy i walki, zaś współpraca i walka kształtują formy, sposoby i przebieg komunikacji. To, jaki kształt przybiera życie społeczne, jest wypadkową tych determinant i form intersubiektywności, wzajemnych proporcji pomiędzy komunikacją, współpracą i walką; w dłuższych okresach utrzymują się one w stanie dynamicznej równowagi, ale w krótszych odcinkach czasowych jakaś determinanta może uzyskać pozycję nieproporcjonalnie dominującą.

Zwykle uznaje się za oczywiste, że w życiu społecznym powinna dominować współpraca. Niemniej jednak, jak szerzej wyjaśniałem w dwóch innych publikacjach [Pleszczyński 2013: 187-189; Pleszczyński 2015a: 119-122], jeśli w triadzie współpraca uzyskuje nieproporcjonalną, zdecydowaną przewagę, to spycha komunikację na pozycję podrzędną, pozostawiając jej tylko funkcje techniczne i strategiczne. Pełna dominacja współpracy sprzyja powstawaniu ultrapragmatycznych i stechnicyzowanych struktur społecznych, których przykładem są współczesne korporacje ${ }^{23}$; w skrajnych przypadkach prowadzi do wytworzenia społeczeństw totalitarnych albo wykreowania utopijnych projektów, których realizacja nieuchronnie rodzi wynaturzenia, przemoc fizyczną i fanatyzm ${ }^{24}$. Aby współpraca nie przybrała form zwyrodniałych, zawsze powinna być poprzedzona komunikacją i porozumieniem - co najmniej w kwestii jej celu.

Porozumienie co do celu nie jest jednak tożsame z jego rozumieniem. Często bowiem jest tak - a w stechnicyzowanych strukturach społecznych staje się to prawie standardem - że ludzie współpracują, bo się porozumieli, mimo że celu nie rozumieją - choćby ze względu na jego złożoność. Podstawowa przyczyna współpracy bez rozumienia leży jednak głębiej; jest nią „technologiczne” przekonanie, że w życiu społecznym współdziałanie to wartość samoistna, bezwzględnie nadrzędna, której wszystkie inne formy intersubiektywności i determinanty życia społecznego powinny być w „naturalny”, a więc oczywisty i niebudzący wątpliwości sposób podporządkowane. Komunikacja zostaje wówczas zredukowana do roli narzędzia i pełni wyłącznie funkcje techniczne. Zapomina się przy tym o jej podstawowej, więziotwórczej funkcji, która realizuje się w komunikacji z empatyczną intencją; trzeba bowiem pamiętać, że komunikacja ujmowana najogólniej jako zbiór relacji, nie musi być „,z konieczności" empatycznie ukierunkowana. Tego typu redukcji komunikacji sprzyja sprzężone z procesami globalizacji i nowoczesnymi technologiami medialnymi przyspieszenie, które sprawia, że komunikacja coraz częściej traktowana jest wyłącznie jako środek do osiągnięcia współpracy, a nie relacja bezinteresownie więziotwórcza, która może, ale niekoniecznie musi owocować współpracą i współdziałaniem.

${ }^{23}$ Można powiedzieć, że takie struktury charakteryzuje współdziałanie autoteliczne; celem i sensem współdziałania jest współdziałanie.

${ }^{24}$ Dobrym przykładem jest XVI-wieczny projekt Tomasza Morusa: gwarantował wolność słowa i tolerancję religijną, ale nie dla ateistów; w projekcie tym ateiści nie mogli również sprawować urzędów publicznych. 
W przeciwieństwie do współpracy walka uważana jest za niepożądaną w życiu społecznym. Niesłusznie; jeśli jest prowadzona według przyjętych w komunikacji i respektowanych reguł oraz występuje w odpowiednich proporcjach w stosunku do dwóch innych determinant życia społecznego, walka działa na rzecz komunikacji, współpracy i współdziałania. Współpraca podjęta z pominięciem walki, np. przez aklamację, jest swoistą formą przemocy; w kategoriach Habermasowskich jest wynikiem działań strategicznych, a nie komunikacyjnych. Tego typu współpraca zasadza się na konwencjach, regułach i konformizmie, a czasem nawet oportunizmie ${ }^{25}$. Walka jest niezbędnym elementem zrównoważonej triady i warunkiem autentycznej akceptacji jakiegoś celu; rzecz jasna, nie może jednak w triadzie dominować. Walka rzutuje na komunikację i współpracę, a jej dominacja skutkuje dekonstrukcją społeczności wedle różnych niewspółmiernych i nieuzgadnialnych celów oraz uporczywym trwaniem przy odrębności działań.

Walka wprowadza do życia społecznego i intersubiektywności najwięcej racjomorficzności, choć jeśli jest prowadzona według ustalonych w komunikacji reguł, to jest to racjomorfizm kontrolowany przez kulturę ${ }^{26}$. Niemniej jednak najgłębsze mechanizmy walki są racjomorficzne, rządzi się ona tymi samymi prawami, które organizują stado; w wyróżnianiu osobników alfa, beta, czy omega chodzi wyłącznie $\mathrm{o}$ ich rolę w zbiorowym działaniu, o dające gwarancję bezpieczeństwa więzi wewnętrzne, bez względu na konkurentów czy nawet wrogów zewnętrznych. Dlatego demokracja, rozumiana jako ustrój i model kultury politycznej [Król 2008: 201] musi dbać o dynamiczną równowagę współpracy, komunikacji i walki.

Na zakończenie tych krótkich uwag należy dodać, że racjonalność wcale nie jest gwarantem współpracy. Przy niedostatku komunikacji ostre konflikty racjonalności prowadzą do dominacji walki, która traci atrybuty prowadzonego według reguł sporu i przeradza się w racjomorficzną agresję. Dlatego komunikacja powinna być dominantą w życiu społecznym; jej eliminacja lub drastyczna redukcja jest równoznaczna z ograniczeniem intersubiektywności i deformacją życia społecznego. Niemniej jednak należy także pamiętać, że komunikacja nie jest gwarancją porozumienia i współpracy - jest tylko, albo aż, obietnicą.

\section{GLOBALIZACJA SOFT I HARD}

Globalizację można rozumieć jako otwieranie się kultur i poszerzanie otoczenia człowieka. U jej podstaw zawsze znajduje się komunikacja. Procesy globalizacji

${ }^{25}$ Warto jednak zaznaczyć, że konformizm nie jest wbrew potocznym opiniom czymś jednoznacznie negatywnym. Kontrolowany konformizm jest strategią przystosowania się jednostki do życia we wspólnocie i nie należy go mylić z niszczącym wspólnotę oportunizmem. Konformizm jest kulturowym analogonem racjomorficznego naśladownictwa.

${ }^{26} \mathrm{Na}$ tego typu walce zasadza się rywalizacja sportowa. Nie chodzi o zniszczenie kogoś, lecz o doskonalenie siebie. 
nie są odkryciem i domeną współczesności; zalążki tendencji globalizacyjnych pojawiły się wraz z intersubiektywnością, a globalizacja $\mathrm{w}$ różnych wymiarach i z różną intensywnością stale była obecna w dziejach cywilizacji. Jednym z najbardziej wyrazistych przykładów globalizacji była epoka hellenistyczna; współcześnie można mówić o „nowym hellenizmie”. Pierwszą fazę ,nowego hellenizmu” dobrze oddaje znana, ale także nadużywana i często źle interpretowana metafora Marshalla McLuhana [1962] - „globalnej wioski”27. W tym pierwszym okresie współczesnej globalizacji jej motorem były tradycyjne media elektroniczne; tego typu globalizację określam mianem globalizacji soft. Dzięki uniwersalnym formatom tworzonym przez instytucjonalnych nadawców środki masowego przekazu pretendowały do statusu narzędzi więziotwórczych. Soft-globalizacja miała być spełnieniem obietnicy projektu nowoczesności. Jak pisał Marshall Berman [2006: 15]: „Być nowoczesnym to znaleźć się w otoczeniu, które obiecuje przygodę, siłę, radość, rozwój, przemianę na samych i świata [...]. Nowoczesne środowiska i doświadczenia nie znają geograficznych, etnicznych, klasowych, narodowych, religijnych ani ideologicznych barier - i w tym sensie nowoczesność jednoczy całą ludzkość" 28 .

Problemy związane z uchodźcami i imigrantami, terroryzmem i ,pełzającą wojną światową" unaoczniają, że faza globalizacji soft już się skończyła; obecnie mamy globalizację typu hard. W odróżnieniu od soft, którą napędzały media elektroniczne i nowoczesne technologie, będące efektem myśli i wyrafinowanych racjonalnych konstrukcji, globalizację hard definiuje fizyczna obecność ludzi. Dlatego z hardglobalizacją wiążą się zupełnie inne problemy - w pewnym sensie analogiczne do tych, które występowały w okresie wielkich wędrówek ludów oraz wówczas, gdy komunikacja była mocno związana z transportem, przemieszczaniem się ludzi i towarów; w takich sytuacjach komunikacja i informacja ${ }^{29}$ były przypisane do jakiegoś materialnego futerału, od którego zostały uwolnione przez elektroniczne i nowe media. Tę jakościową zmianę w problematyce i dyskursie dotyczącym globalizacji wymusza to, że każda „zmasowana” zbiorowość bardzo wyraźnie się odróżnia i wyróżnia, choć sama sprawia wrażenie niezróżnicowanej wewnętrznie. Masa redukuje albo wręcz eliminuje komunikację ze sfery intersubiektywności; w hard-globalizacji dominantą staje się walka. Redukcja komunikacji wzmacnia to, co w filozofii nazywa się materializmem i pragmatyzmem; cała reszta to w hard-globalizacji ozdobniki bez znaczenia.

${ }^{27}$ Paul Levinson [2001: 65-79], uczeń McLuhana (i Poppera) szeroko uzasadnia - choć nie wszystkie argumenty są przekonujące - że epoka internetu potwierdziła trafność metafory „globalna wioska”. Według Ryszarda Kapuścińskiego [2007: 109] nowoczesne technologie komunikacyjne wytworzyły ,globalne miasto”, a nie ,globalną wioskę” - świat zdezintegrowanych jednostek, w którym „nikt z nikim nie rozmawia, nikim się nie interesuje". Opinia ta pochodzi z 2003 r., z wywiadu, który przeprowadził Edwin Bendyk, a opublikował „Przegląd Polityczny” nr 62/63. Wywiad został włączony do tomu Lapidarium VI.

${ }^{28}$ Procesy te bardzo dobrze i przejrzyście opisano i wyjaśniono w dostępnej w polskim tłumaczeniu książce Johna B. Thompsona [2006: 153-182].

${ }^{29}$ Komunikacji nie można oczywiście redukować do informacji; komunikacja to relacja społeczna, w którą musi być zaangażowany nadawca i odbiorca, natomiast informacja może istnieć bez odbiorcy. 
Globalizacja soft jest - a może już tylko była - „miękka”, medialna, zapośredniczona; wykazywała tendencje uniwersalistyczne, scalające i ujednolicające, ale nie „dotykała” bezpośrednio indywidualnego człowieka ${ }^{30}$. Globalizacja hard ma charakter fizyczny i bezpośredni, a fizyczność i bezpośredniość, połączone z innością, zawsze wzmacniają racjomorfizm. Miękka, związana z technologiami i mediami soft-globalizacja musi więc ustąpić przed twardą fizycznością, materią i praktyką globalizacji typu hard, w której racjomorficzność jednoznacznie wskazuje, że „inni” $\mathrm{i}$ „obcy” są groźni i gorsi oraz podpowiada jednoznaczne zerojedynkowe reakcje ${ }^{31}$. W fizycznym kontakcie inny i obcy okazuje się także niezrozumiały. Co więcej, wyzwolony w hard-globalizacji racjomorfizm nie jest niewinnym racjomorfizmem. Jak pisałem w innym miejscu [Pleszczyński 2013: 188-189, 321], racjomorficzna agresja i obronność zwierząt nie występuje u ludzi w czystej postaci, a człowiek, który odrzuca wartości i normy kulturowe, nie cofa się na pozycje poczciwego zwierzęcia, lecz po prostu się degeneruje.

Komunikacja w hard-globalizacji przybiera nowe formy. Z jednej strony determinują ją nowoczesne, niematerialne technologie, $\mathrm{z}$ drugiej zaś formy znane z odległej przeszłości, w której komunikacja była związana z fizycznością, cielesnością, bezpośrednimi i bezrefleksyjnymi spostrzeżeniami i wrażeniami, tym co bezpośrednio widzialne - czyli z racjomorficznością. Informacyjny nadmiar e-komunikacji oraz fizycznych kontaktów, powiązań i relacji sprawia, że człowiek się gubi; w nadmiarze nie gubi się tylko komputer. Nadmiar wprowadza chaos i utrudnia, a często uniemożliwia porozumienie i rozumienie; człowiek zaczyna poszukiwać najprostszych rozwiązań i dlatego relacje z innymi ludźmi i światem stają się w coraz większym stopniu racjomorficzne.

\section{KOMUNIKACYJNY AKSJOMORFIZM: POROZUMIENIE POZA ROZUMIENIEM}

W postmodernistycznym, pluralistycznym i zglobalizowanym świecie racjonalność nie może pełnić roli fundamentu międzyludzkiego porozumienia; nie ma już wspólnej racjonalności, wspólnej wiedzy i wspólnego rozumu. W dominującej współcześnie formie komunikacji status praw uniwersalnych zyskały prawa technologiczne, a media przejęły wszelkie funkcje, jakie wcześniej pełniła kultura; przejęły jej status, kształtując indywidualne myśli i zbiorowe wyobrażenia. Nowe media nie

\footnotetext{
${ }^{30}$ Oczywiście stwarzała także swoje własne, specyficzne problemy, znane np. jako imperializm kulturowy czy transkulturacja, ale tutaj je pomijam.

31 Wprawdzie - jak wyjaśniałem wcześniej - nowoczesne technologie są kryjówką dla racjomorfizmu, ale „racjomorfizm technologiczny” nie jest tym samym co „racjomorfizm biologiczny”. Nowoczesne technologie działają według mechanizmów racjomorficznych i dlatego promują, a nawet wymuszają racjomorficzne zachowania. Niemniej jednak „technoracjomorfizm” w przestrzeni cyfrowej jest czymś innym niż racjomorfizm w przestrzeni fizycznej.
} 
są, jak kultura, filtrem rzeczywistości, lecz samą rzeczywistością; współczesny obraz świata jest w zasadzie tożsamy z medialnym obrazem świata.

Procesy globalizacji radykalnie zmieniły ludzkie doświadczenie oparte na indukcji, która od tysięcy lat stanowi mechanizm kształtowania obrazów i wizji świata; do niedawna była łącznikiem osobistego doświadczenia z tym, co Popper [1992] nazwał „wiedzą obiektywną”, Ian Stewart i Jack Cohen [2003] „eksteligencją”. W epoce soft-globalizacji indukcja stała się łącznikiem z obrazami i supozycjami medialnymi, bo współcześnie to właśnie one są tym, co wspólne, zaś globalizacja typu hard z całą mocą wydobyła z człowieka racjomorfizm. Wyznacznikiem hard-globalizacji jest niezróżnicowana „masa”, jednolita całość wyzwalająca u pojedynczych ludzi racjomorficzny lęk i agresję. Z masą nie można się porozumieć ani jej zrozumieć, jest irracjonalna, nieprzewidywalna, spontaniczna, potężna i obca. Jak pisał Elias Canetti [1996: 17], masa „nie uznaje domów, drzwi i zamków”, niczego, co indywidualne i poza masą. W masie nie ma racjonalności. Z drugiej strony indywidualny człowiek poddany jest stałej presji mediów i technologii medialnych, które działają wedle mechanizmów racjomorficznych. Naturalny racjomorfizm jest wzmacniany przez racjomorfizm technologiczny i vice versa.

Dochodzę wreszcie tutaj do kluczowego miejsca rozważań. Otóż może być tak ale nie musi - że najbardziej racjonalną, choć oczywiście nie jedyną strategią dającą nadzieję na międzyludzkie porozumienie okaże się odwołanie do jedności gatunkowej Homo sapiens socialis et communicans, czyli do racjomorfizmu. Paradoks jest pozorny: chodzi bowiem o jego specyficzną formę, ,pozytywny racjomorfizm”, który określiłem wcześniej jako aksjomorfizm; w nim tkwi niewykorzystany potencjał jednoczenia ludzkości w ramach gatunku, który może wspierać pozytywne aspekty procesów globalizacji i neutralizować aspekty negatywne. Taki ,zwrot aksjomorficzny", przez wydobycie z pokładów racjomorficzności empatii i sympatii, sprzyja też ograniczaniu mocy racjomorfizmu technologicznego. Racjomorfizm technologiczny i masy potęgują lęki i agresję; jej ogranicznikiem są bezpośrednie, a nie masowe i technologicznie zapośredniczone kontakty. Empatia i sympatia odnoszą się zawsze do pojedynczych osób. Co więcej, oparte na aksjomorfizmie empatia i sympatia pozwalają, przynajmniej od czasu do czasu, na „prawdziwą” relację face-to-face, a nie mask-to-mask, jak w przypadku relacji wtłoczonych w gorset współczesnych rytuałów cywilizacyjnych, czy interface-to-interface, jak w przypadku komunikacji w nowych mediach [Pleszczyński 2014].

Odwołanie się do mechanizmów racjo- i aksjomorficznych nie oznacza zgody na redukcję sfery społecznej i intersubiektywności. Zwracali na to uwagę wybitni przedstawiciele ewolucyjnej teorii poznania, przede wszystkim Konrad Lorenz [1996] i Irenäus Eibl-Eibesfeldt [1997]. W opublikowanej w połowie lat 60. XX w. książce pod znamiennym tytułem Tak zwane zło Lorenz, późniejszy laureat Nagrody Nobla w dziedzinie fizjologii i medycyny, zmierzył się z problemem ewolucyjnej genezy ludzkiej agresji. Wskazywał, że u wszystkich zwierząt agresja wewnątrzgatunkowa jest „tak zwanym złem”; tak zwanym, bo stanowi niezbędny element życia. Lorenz 
i Eibl-Eibesfeldt przekonująco wykazywali, w jaki sposób wewnątrzgatunkowa agresja u zwierząt jest rytualizowana, osłabiana i właściwie ukierunkowywana. Lorenz pisał [1996: 280] o ,zachowaniu zbieżnym z moralnością”, czyli o aksjomorfizmie. Upraszczając, można powiedzieć, że w świecie zwierząt agresja wewnątrzgatunkowa nie tylko nie stanowi zagrożenia, ale jest konieczna dla bezpieczeństwa grupy, natomiast $\mathrm{w}$ świecie ludzkim stała się rzeczywistym, a nie pozornym złem. Jak pisze Lorenz [1996: 279]: „Poznanie, wywodzące się z myślenia pojęciowego, wygnało człowieka z raju, w którym mógł swobodnie puszczać wodze swoim instynktom i czynić to, na co miał ochotę".

Chodzi o to, że wraz z myśleniem pojęciowym do ewolucji biologicznej dołączyła ewolucja kulturowa i technologiczna, a wraz z nimi zupełnie nowe formy i możliwości działania. Po pierwsze, człowiek stworzył narzędzia, których mógł używać jako śmiercionośnej broni. Zwierzęta żadną nienaturalną bronią nie dysponują, więc wewnątrzgatunkowa walka rzadko kończy się śmiercią. Po drugie, u współczesnego Homo sapiens socialis et communicans selekcja jest sprzężona $\mathrm{z}$,konkurencyjnością komercjalną”: „Na instynktownym podłożu gromadzenia majątku, na popędzie ambicji itp. opiera się wysoka pozytywna premia selekcyjna, na prostej przyzwoitości - prawie równie wysoka negatywna premia selekcji” [Lorenz 1996: 287]. Po trzecie, rzeczywistemu, a nie tak zwanemu złu, sprzyja tempo ewolucji kulturowej. „W miarę coraz wyższego rozwoju cywilizacji wszystkie warunki sprzyjające właściwemu działaniu naszych naturalnych skłonności do społecznego zachowania się stają się coraz mniej korzystne" [Lorenz 1996: 292]. Jak widać, zjawiska te są sprzężone z dość oczywistym faktem, że człowiek już od dawna nie żyje w przyrodzie; środowiskiem naturalnym człowieka nie jest przyroda, lecz technologie, a historia cywilizacji to historia oddalania się od natury.

Agresję wewnątrzgatunkową, która w przypadku ludzi jest prawdziwym, a nie pozornym złem, wspomagają i napędzają nowoczesne technologie komunikacyjne - motor soft-globalizacji, masy charakterystyczne dla globalizacji typu hard i przyspieszenie wszystkiego. To sprawia, że nie ma czasu ani obszaru nie tylko na rozumienie, ale także na porozumienie.

Przypomnę, że rozumienie i porozumienie nie są tym samym. W ujęciu teoretycznym rozumienie to „sytuacja poznawcza”, zaś porozumienie to „sytuacja etyczna": mimo że nie rozumiem, to chcę nawiązać więź. Rozumienie jest stanem świadomości indywidualnego człowieka, chodzi przede wszystkim o rozumienie świata i nadawanie mu sensu. Tam, gdzie nie ma sensu, nie ma też rozumienia; sens porządkuje słowa i dyskursy. Porozumienie natomiast - jak pisałem w innym artykule [Pleszczyński 2015b: 334], ,zawsze ma charakter społeczny; do porozumienia potrzebne są co najmniej dwie osoby. Jest strategią wspólnotową [...]. Fundamenty porozumienia są silnie racjomorficzne, bo jego pierwotną, biologiczną funkcją jest wytworzenie wspólnotowych więzi i zwiększenie szansy przeżycia jednostek". W aksjomorficznym porozumieniu nie chodzi o nadawanie sensu; sens jest wytwarzany w myślach, języku, kulturze, a nie w racjo- i aksjomorficzności. Racjonalne 
porozumienie chce być po-rozumieniem, domaga się wcześniejszego rozumienia, natomiast $\mathrm{w}$ porozumieniu aksjomorficznym chodzi o więź, która może powstać i trwać poza i bez rozumienia. Rozumienie i porozumienie osiągane na bazie racjonalności i od początku ukierunkowane na skuteczną współpracę wymagają języka jako narzędzia komunikacji, natomiast więziotwórcze porozumienie może się oprzeć na aksjomorficzności, pozytywnej racjomorficzności, komunikacji, w której dominantą jest empatia i sympatia, a język pełni funkcje dopełniające.

Stan porozumienia bez rozumienia, którego fundamentem jest empatia i sympatia, wspólna wszystkim ludziom, bo racjomorficzna, można nazwać „komunikacyjnym aksjomorfizmem", polegającym na bezwarunkowej i niepowątpiewalnej - bo opartej na racjomorficznym poczuciu wspólnoty gatunkowej - akceptacji, że inny i obcy jest człowiekiem. W sytuacjach, w których z jakichś powodów rozumienie i racjonalne porozumienie nie są możliwe, albo bardzo trudne - a jak się wydaje, takich sytuacji w epoce hard-globalizacji jest i będzie coraz więcej - komunikacyjny aksjomorfizm nie pozwala, by pozbawiona reguł uzgodnionych w komunikacji racjomorficzna walka stała się dominantą intersubiektywności i życia społecznego. Intersubiektywność i sfera społeczna nie zostają wówczas zredukowane wyłącznie do dwóch form: walki i racjomorficznej współpracy bez rozumienia; komunikacja, choć aksjomorficzna, jest w niej zachowana, pozostawiając furtkę i nadzieję na zrozumienie i racjonalną, ale też empatyczną współpracę - w przyszłości.

\section{ZAKOŃCZENIE}

Aksjomorfizm to zupełnie inna przestrzeń dla porozumienia niż sfera rozumu albo wiary; nie można w nim szukać ani racjonalności, ani utożsamiać go z irracjonalizmem $^{32}$. Odwołanie się do aksjomorficzności tylko pozornie może wydawać się naiwne; zarzut, że empatia i sympatia od dawna są obecne i dobrze zakorzenione w kulturze, choćby w judeochrześcijańskim nakazie miłości bliźniego, jest nietrafny. Źródła aksjomorfizmu tkwią z naturze, sile starszej i mocniejszej, a zatem - w pewnych warunkach - skuteczniej działającej niż kultura, której reguły - w pewnych warunkach - okazują się bardzo labilne. Jak starałem się wykazać w tym artykule, współcześnie, w epoce nowych mediów i globalizacji, z takimi warunkami spotykamy się coraz częściej.

Oczywiste jest, że wszelkie przeorganizowania sfery społecznej poprzedzone są zjawiskami komunikacyjnymi. Relacje komunikacyjne działają, oddziałują i przekładają się na inne relacje tworzące tkankę społeczną. Nowe media i procesy globalizacji rewolucjonizują komunikację, ustanawiają dla niej nowe reguły, nadają nowe formy

\footnotetext{
${ }^{32}$ Nie jest moją intencją sugerowanie, że wiara jest czymś irracjonalnym. Wielu filozofów, m.in. Józef Życiński [2002 i in.] i papież Jan Paweł II w encyklice Fides et Ratio, wskazywało na komplementarność rozumu i wiary. Na ten temat napisano zresztą tysiące prac - i zgody nie osiągnięto.
} 
i ramy. Z tego właśnie powodu Barbara Skarga już prawie dekadę temu uznała [2007: 320], że nowe media i nowe formy komunikacji są dziś najpoważniejszym wyzwaniem dla nauk społecznych i humanistyki. One też będą decydować albo ostrożniej: współdecydować, o kształcie demokracji i kultury. W działaniach i zachowaniach komunikacyjnych rodzi się rozumienie i porozumienie, tworzą międzyludzkie więzi.

W artykule starałem się - z konieczności bardzo skrótowo, upraszczająco i ogólnikowo - pokazać, że zarówno nowoczesnymi technologiami komunikacyjnymi, jak i pewnymi zjawiskami globalizacyjnymi rządzą mechanizmy racjomorficzne; m.in. dlatego także w zjawiskach komunikacyjnych odnajdujemy coraz więcej racjomorfizmu. Wzrost znaczenia czynników racjomorficznych w sferze intersubiektywności i życiu społecznym domaga się poważnego potraktowania i gruntownego przemyślenia. Uważam, że inspiracji można szukać w ideach zrodzonych w kręgu Konrada Lorenza. Mimo że większość z nich powstała 30, 40, 60, a niektóre nawet 75 lat temu [zob. Lorenz 1941], to, jak się wydaje, wciąż są mało obecne nie tylko w tzw. świadomości potocznej, ale też w naukach społecznych, politycznych, humanistyce, filozofii. Sądzę, że w obliczu problemów, które obecnie nękają Europę i świat, jak wielkie migracje, terroryzm, narastające nierówności społeczne, kryzys demokracji liberalnej itd., potrzebą chwili jest przypomnienie, przemyślenie i praktyczne wykorzystanie podstawowego przekazu Lorenza [1996: 273], takiego mianowicie, że „wzrost wiedzy o naturalnych przyczynach własnego zachowania się może znakomicie zwiększyć możliwości działania człowieka i nadać mu władzę przekształcania wolnej woli w czyn". Parafrazując przytaczane wcześniej słowa Jana Woleńskiego można powiedzieć, że racjonalności w komunikacji i życiu społecznym nie da się niczym innym zastąpić, ale bezkrytyczna wiara w racjonalność komunikacyjną prowadzi do istotnych zagrożeń cywilizacyjnych. Diagnoza ta jest szczególnie ważna w dobie globalizacji.

\section{BIBLIOGRAFIA}

Amsterdamski, S. 1983. Między historia a metodą. Spory o racjonalność nauki, Państwowy Instytut Wydawniczy, Warszawa.

Baynes, K. 2008. Habermas, [w:] Myśliciele polityczni. Od Sokratesa do wspótczesności, D. Boucher, P. Kelly (red.), Wydawnictwo Uniwersytetu Jagiellońskiego, Kraków.

Berman, M. 2006. ,W Wzystko co state, rozplywa się w powietrzu”. Rzecz o doświadczeniu nowoczesności, tłum. M. Szuster, Wydawnictwo Universitas, Kraków.

Brunswik, E. 1955. „Ratiomorphic” Models of Perception and Thinking, „Acta Psychologica”, nr 11.

Canetti, E. 1996. Masa i władza, tłum. E. Borg, M. Przybyłowska, Wydawnictwo Czytelnik, Warszawa.

Castells, M. 2013. Władza komunikacji, tłum. J. Jedliński, P. Tomanek, Wydawnictwo Naukowe PWN, Warszawa.

Eibl-Eibelsfeldt, I. 1997. Mitość i nienawiść. Historia naturalna elementarnych sposobów zachowania się, thum. Z. Stromenger, Państwowy Instytut Wydawniczy, Warszawa.

Galton, H. 1990. Komunikacja a rozumienie, thum. A. Przyłębski, [w:] Komunikacja-rozumienie - dialog, B. Andrzejewski (red.), Wydawnictwo Uniwersytetu Adama Mickiewicza, Poznań. 
Gleick, J. 2002. Szybciej. Przyspieszenie niemal wszystkiego, thum. J. Bieroń, Wydawnictwo Zysk i S-ka, Poznań.

Habermas, J. 1999. Teoria działania komunikacyjnego. Racjonalność działania a racjonalność spoleczna, t. 1, tłum. A.M. Kaniowski, Wydawnictwo Naukowe PWN, Warszawa.

Habermas, J. 2002. Teoria dziatania komunikacyjnego. Przyczynek do krytyki rozumu funkcjonalnego, t. 2, thum. A.M. Kaniowski, Wydawnictwo Naukowe PWN, Warszawa.

Kałuszyńska, E. 2005. Wiedza i informacja, [w:] Informacja a rozumienie, M. Heller, J. Mączka (red.), Wydawnictwo Biblos, Tarnów.

Kapuściński, R. 2007. Lapidarium VI, Wydawnictwo Czytelnik, Warszawa.

Król, M. 2008. Filozofia polityczna, Wydawnictwo Znak, Kraków.

Król, M. 2015. Kłamcy będa ptonać w piekle, „Gazeta Wyborcza”, nr 237.

Levinson, P. 2001. Digital McLuhan. A guide to the information millennium, Routledge. Taylor \& Francis Group, London and New York.

Lorenz, K. 1941. Kants Lehre vom Apriorischen im Lichte gegenwärtiger Biologie, „Blätter für Deutsche Philosophie", nr 15.

Lorenz, K. 1953. King Solomon's Ring. New Light on Animals Ways, The Reprint Society, London.

Lorenz, K. 1986. Regres czlowieczeństwa, thum. A.D. Tauszyńska, Państwowy Instytut Wydawniczy, Warszawa.

Lorenz, K. 1996. Tak zwane zło, thum. A.D. Tauszyńska, Państwowy Instytut Wydawniczy, Warszawa.

Marczewska-Rytko, M. 2002. Procesy globalizacji a demokracja bezpośrednia, [w:] Oblicza procesów globalizacji, M. Pietraś (red.), Wydawnictwo Uniwersytetu Marii Curie-Skłodowskiej, Lublin.

McLuhan, M. 1962. The Gutenberg Galaxy, Mentor, New York.

Nisbett, R.E. 2015. Geografia myślenia. Dlaczego ludzie Wschodu i Zachodu myśla inaczej?, tłum. E. Wojtych, Wydawnictwo Smak Słowa, Sopot.

Pietraś, M. 2002. Wstęp, [w:] Oblicza procesów globalizacji, M. Pietraś (red.), Wydawnictwo Uniwersytetu Marii Curie-Skłodowskiej, Lublin.

Pleszczyński, J. 2011. Dyskurs medialny z perspektywy epistemologicznej, [w:] Dyskursy komunikacji medialnej, A. Filipczak-Białkowska (red.), Wydawnictwo Primum Verbum, Łódź.

Pleszczyński, J. 2013. Epistemologia komunikacji medialnej. Perspektywa ewolucyjna, Wydawnictwo Uniwersytetu Marii Curie-Skłodowskiej, Lublin.

Pleszczyński, J. 2014. Maska i anonimowość jako problem komunikacyjny, [w:] Literatura, media, polityka, M. Piechota (red.), Wydawnictwo Uniwersytetu Marii Curie-Skłodowskiej, Lublin.

Pleszczyński, J. 2015. Światoobrazy, obrazy świata i wizje świata, [w:] Wspótczesne media. Medialny obraz świata, I. Hofman, D. Kępa-Figura (red.),Wydawnictwo Uniwersytetu Marii Curie-Skłodowskiej, Lublin.

Pleszczyński, J. 2015a. Etyka dziennikarska i dziennikarstwa, Wydawnictwo Difin, Warszawa.

Pleszczyński, J. 2015b. Wyobraźnia i porozumienie, [w:] W poszukiwaniu osobliwości natury ludzkiej, A. Gut, Z. Wróblewski (red.), Wydawnictwo Katolickiego Uniwersytetu Lubelskiego, Lublin.

Popper, K.R. 1987. Die erkenntnistheoretische Position der Evolutionären Erkenntnistheorie, [w:] Die Evolutionären Erkenntnistheorie. Bedingungen - Lösungen - Kontroversen, F.M. Wuketits, R. Riedl (red.), Paul Parey Verlag, Berlin/Hamburg.

Popper, K.R. 1992. Wiedza obiektywna. Ewolucyjna teoria epistemologiczna, thum. A. Chmielewski, Wydawnictwo Naukowe PWN, Warszawa.

Popper, K.R., Lorenz K. 1985. Die Zukunft ist offen, Piper \& Co Verlag, München.

Robertson, R. 1992. Globalization. Social Theory and Global Culture, Sage, London.

Rutkowski, K. 2015. Paryża nie da się zniszczyć, „Gazeta Wyborcza”, nr 271.

Skarga, B. 2007. „Innego końca świata nie będzie”. Z Barbara Skarga rozmawiaja Katarzyna Janowska i Piotr Mucharski, Wydawnictwo Znak, Kraków.

Skibiński, A. 2012. Gregory Bateson i kontekstowa teoria komunikacji. Różnica, która czyni różnicę i wzorzec, który łączy, [w:] Komunikologia. Teoria i praktyka komunikacji, E. Kulczycki, M. Wendland (red.), Wydawnictwo Naukowe IF UAM, Poznań. 
Spaemann, R., Löw, R. 2008. Cele naturalne. Dzieje i ponowne odkrycie rozumu teleologicznego, thum. A. Półtawski, Oficyna Naukowa, Warszawa.

Stewart, I., Cohen, J. 2003, Wytwory rzeczywistości, tłum. W. Stępień-Rudzka, Wydawnictwo Prószyński i S-ka, Warszawa.

Szacki, J. 2003. Historia myśli socjologicznej, Wydawnictwo Naukowe PWN, Warszawa.

Thompson, J.B. 2006. Media i nowoczesność. Spoleczna teoria mediów, Wydawnictwo Astrum, Wrocław. Watzlawick, P., Beavin, J.H., Jackson, D.D. 1967. Pragmatics of Human Communication: A Study of Interactional Patterns, Pathologies, and Paradoxes, Norton, New York.

Wendland, M. 2014. Filozoficzne i metodologiczne podstawy historii komunikacji, Wydawnictwo Naukowe Uniwersytetu Adama Mickiewicza, Poznań.

Woleński, J. 2015. Stefan Amsterdamski, filozof, „Gazeta Wyborcza” nr 261.

Życiński, J. 2002. Bóg i ewolucja. Podstawowe pytania ewolucjonizmu chrześcijańskiego, Towarzystwo Naukowe KUL, Lublin.

\section{ABSTRACT}

The article concerns contemporary problems of intersubjectivity. It is in intersubjectivity that understanding and agreement are born. Because of the new media and the processes of globalization, rationality, culture, and knowledge can no longer constitute the only foundation for understanding and agreement - since there is no common rationality, culture, and knowledge anymore.

In the article, I support a thesis that in the world that is global but, at the same time, fragmentized on a scale unknown in previous media epochs, agreement is much more important than understanding. It is necessary to agree even without understanding. Thus, one should seek the foundations for agreement in ratiomorphism as well - rather than only in rationality; ratiomorphism is common to all people irrespective of culture, religion, social status, worldview, etc.

A "positive" form of ratiomorphism is axiomorphism, in which biologically determined empathy and liking for fellow Homo sapiens socialis et communicans manifests itself. Referring to Konrad Lorenz's idea, I suggest that Habermas's communicative rationality should not be so much replaced as complemented by communicative axiomorphism.

Key words: communication, communication theory, new media, globalization, epistemology, intersubjectivity, understanding, agreement, subjectivity

BIOGRAM

Jan Pleszczyński, adiunkt w Zakładzie Komunikacji Społecznej Wydziału Politologii UMCS, absolwent biologii (UMCS 1981), doktor filozofii (KUL 1997), doktor habilitowany w zakresie nauk o polityce (UMCS 2014). Ostatnio opublikował książki: Epistemologia komunikacji medialnej. Perspektywa ewolucyjna (Lublin 2013) książka otrzymała wyróżnienie rektora Uniwersytetu Warszawskiego - oraz Etyka dziennikarska i dziennikarstwa (Warszawa 2015). Kontakt e-mail: jpp@autograf.pl. 